\title{
Pengaruh Tax Amnesty, Sanksi Perpajakan dan Kualitas Pelayanan Fiskus terhadap Kepatuhan Wajib Pajak Orang Pribadi
}

\section{A.A. Sagung Shinta Devi Darmayani ${ }^{1}$ \\ Fakultas Ekonomi dan Bisnis Universitas Udayana, Indonesia}

\author{
I Ketut Budiartha ${ }^{2}$ \\ Fakultas Ekonomi dan Bisnis \\ Universitas Udayana, Indonesia
}

\section{ABSTRAK}

Penelitian ini bertujuan untuk mengetahui pengaruh tax amnesty, sanksi perpajakan dan kualitas pelayanan fiskus pada kepatuhan wajib pajak orang pribadi yang dilakukan di KPP Pratama Badung Utara. Teknik pengambilan sampel menggunakan Metode Accidental Sampling dengan jumlah sampel yang diambil sebesar 100 responden. Teknik analisis data yang digunakan yaitu uji stastitik deskriptif, uji asumsi klasik dan regresi linier berganda. Berdasarkan hasil analisis yang dilakukan, didapatkan hasil bahwa tax amnesty, sanksi perpajakan dan kualitas pelayanan fiskus berpengaruh terhadap kepatuhan wajib pajak orang pribadi yang terdaftar di KPP Pratama Badung Utara.

Kata Kunci: Tax Amnesty; Sanksi Perpajakan; Kualitas Pelayanan Fiskus; Kepatuhan Wajib Pajak Orang Pribadi.

\section{The Effect of Tax Amnesty, Tax Sanction and Tax Quality Service of Personal Taxpayers Compliance}

\begin{abstract}
This study has a purpose to determine the effect of tax amnesty, tax sanctions and the quality of tax authorities on compliance of individual taxpayers that conducted at KPP North Badung. The number of sample are 100 respondents by using accidental sampling methods. Data analysis technique that used are descriptive statistical test, classic assumption test and multiple linear regression. Based on the results of testing conducted, it is known that tax amnesty, tax sanctions and the quality of tax authorities have an effect on the compliance of individual taxpayers registered in KPP North Badung.
\end{abstract}

Keywords: Tax Amnesty; Tax Sanction; Service Quality; Taxpayers Compliance.

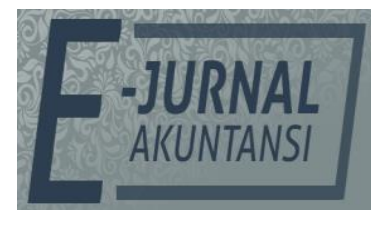

e-ISSN 2302-8556

Vol. 30 No. 10

Denpasar, Oktober 2020

Hal. 2444-2455

DOI:

10.24843/EJA.2020.v30.i10.p01

PENGUTIPAN:

Darmayani, A. A. S. S.D. \& Budiartha, I K. (2020).

Pengaruh Tax Amnesty, Sanksi Perpajakan dan Kualitas Pelayanan Fiskus Terhadap Kepatuhan Wajib Pajak Orang Pribadi. E-Jurnal Akuntansi, 30(10), 2444-2455

RIWAYAT ARTIKEL:

Artikel Masuk: 11 Februari 2020 Artikel Diterima:

12 Juli 2020

Artikel dapat diakses : https://ojs.unud.ac.id/index.php/Akuntansi/index 


\section{PENDAHULUAN}

Pajak adalah pungutan wajib yang dikenakan kepada rakyat oleh Negara yang berdasarkan Undang-Undang dan akan digunakan kembali untuk kepentingan publik (Olaoye et al., 2017). Pajak dianggap dapat mengukur kemandirian suatu negara dikarenakan penerimaan pajak digunakan untuk membiayai pembangunan dan pengembangan infrastruktur yang berasal dari rakyat (Pravasanti, 2018). Penerimaan Negara Indonesia dalam Anggaran PendapatanBelanja-Negara (APBN).

Tabel 1. Pendapatan Negara Indonesia dalam APBN 2019

\begin{tabular}{llcc}
\hline No & \multicolumn{1}{c}{ Sumber } & $\begin{array}{c}\text { Jumlah (dalam } \\
\text { triliun rupiah) }\end{array}$ & $\begin{array}{c}\text { Persentase } \\
\text { (persen) }\end{array}$ \\
\hline 1 & Pajak & $1.786,4$ & 82,50 \\
2 & Pendapatan negara bukan pajak & 378,3 & 17,48 \\
3 & Hibah & 0,4 & 0,02 \\
& Total & $2.165,1$ & 100 \\
\hline
\end{tabular}

Sumber: Kementrian Keuangan Republik Indonesia, 2019

Pajak menyumbangkan 82,50 persen dari seluruh pendapatan negara di tahun 2019. Pemerintah Indonesia dihadapkan dengan rasio pajak yang tidak maksimal, hal ini mengakibatkan tingkat dari kepatuhan wajib pajak masih tergolong rendah (Mujahid \& Ahmed, 2019). Penyebab masih rendahnya kepatuhan masyarakat dalam membayar pajak dikarenakan ketidaktahuan atau kurangnya kesadaran masyarakat akan peraturan perpajakan (Hayat \& Kristanto, 2018). Pemerintah Indonesia telah mengeluarkan kebijakan tax amnesty yang sebelumnya pernah dilakukan pada beberapa tahun yang lalu, hal ini bertujuan untuk mengatasi permasalahan wajib pajak (Darmawan, 2016). Tax amnesty pada tahun 1984 dianggap kurang berhasil karena respon dari wajib pajak yang masih rendah (Diamastuti \& Hardanti, 2019). Tax Amnesty periode pertama yang dimulai tanggal 28 Juni hingga 30 September 2016, kemudian dilanjutkan dengan periode kedua dimulai tanggal 1 Oktober hingga 31 Desember 2016 dan berakhir di periode ketiga dimulai tanggal 1 Januari dan berakhir tanggal 31 Maret 2017 (Fitria et al., 2019). Penerapan kebijakan tax amnesty disebabkan oleh penurunan ekonomi secara global, aktivitas perdagangan menurun yang diikuti oleh kenaikan harga dari kegiatan ekspor dan impor (Natania, 2018). Tax amnesty juga bertujuan untuk repratiasi aset atau proses pengembalian akumulasi penghasilan wajib pajak yang berupa aset atau harta diluar wilayah Negara Indonesia (Sumanjaya, 2019). Tax amnesty diharapkan mampu untuk meningkatkan penerimaan negara khususnya dalam penerimaan pajak (Susan, 2018).

Peran pajak yang diharapkan sebagai salah sumber pendapatan terbesar, ternyata masih terdapat kendala wajib pajak yang tidak melaporkan harta kekayaannya kepada negara sehingga penerimaan pajak yang diperoleh tidak maksimal (Istighfarin \& Fidiana, 2018). Ketidakpatuhan yang dilakukan oleh wajib pajak seperti ini yang menyebabkan pendapatan negara tidak sesuai dengan yang diharapkan oleh pemerintah. Pemerintah menerapkan sistem selfassessment berupa wewenang dan kepercayaan kepada wajib pajak dalam menghitung dan melaporkan pendapatannya yang harus dibayar sesuai dengan Undang-Undang perpajakan (Damayanti et al., 2015). Konsekuensi dari 
penerapan sistem self-assessment adalah penerimaan pajak suatu Negara sangat berpengaruh kepada patuhnya dan benarnya perhitungan yang dilaporkan oleh wajib pajak (Suyanto \& Pratama, 2018).

Kepatuhan wajib pajak merupakan keadaan wajib pajak mematuhi aturan dan melaporkan pendapatan perpajakannya secara akurat dan sebenarbenarnya (Nuryati \& Pratama, 2019). Penerimaan pajak negara akan meningkat seiring dengan patuhnya wajib pajak dalam membayar pajak (Wiryadana \& Lely, 2018). Pemerintah mengatasi ketidakpatuhan dari wajib pajak, pemberian sanksi pun diberlakukan bagi wajib pajak yang melanggar peraturan perpajakan (Saraswati et al., 2018). Sanksi mengenai perpajakan diatur dalam UndangUndang Nomor 28 Tahun 2007 mengenai Ketentuan Umum dan Tata Cara Perpajakan (Sari \& Mulyati, 2018). Sanksi dalam perpajakan terdapat dua sanksi, yaitu sanksi pidana dan sanksi administrasi. Sanksi pidana merupakan hukuman yang diberikan kepada pelanggar dalam bentuk fisik seperti kurungan penjara, sedangkan sanksi administrasi merupakan pembayaran kerugian kepada negara khususnya berupa bunga, denda dan kenaikan pajak yang terutang (Wirawan \& Noviari, 2018). Sanksi mengenai tax amnesty diatur dalam "Pasal 18 UU No.11 Tahun 2016" yang menjelaskan sanksi administrasi akan dikenakan kepada wajib pajak yang belum atau kurang dalam mengungkap hartanya akan dikenakan kenaikan sebesar 200 persen sampai dengan akhir periode tax amnesty (Dewi \& Noviari, 2017). Pemberian sanksi kepada pelanggar pajak diharapkan mampu untuk menyadarkan wajib pajak atas kesalahannya (Purnamasari \& Sudaryo, 2018). Tingkat kepatuhan wajib pajak dapat dipengaruhi oleh faktor luar, salah satunya adalah kualitas pelayanan fiskus kepada wajib pajak. Pelayanan oleh aparatur pajak yang baik dan dapat membantu wajib pajak dalam administrasi perpajakan. Terdapat lima kriteria kualitas layanan sebagai berikut. 1) nyata, 2) kehandalan, 3) responsif, 4) jaminan dan 5) empati (Jaya et al., 2017). Sudut pandang wajib pajak terhadap kualitas pelayanan fiskus yang baik adalah penilaian wajib pajak pada keseluruhan kualitas pelayanan yang dilakukan oleh fiskus di kantor pelayanan pajak yang bersangkutan (Madjid, 2015). KPP Pratama Badung Utara menyampaikan bahwa sampai tanggal 28 Oktober 2019, jumlah WPOP terdaftar sebanyak 75.361 orang.

Tabel 2. Tingkat Kepatuhan WPOP di KPP Pratama Badung Utara Tahun 20152018

\begin{tabular}{cccccc}
\hline No & Tahun & $\begin{array}{c}\text { WPOP Wajib } \\
\text { Lapor (orang) }\end{array}$ & $\begin{array}{c}\text { WPOP sudah } \\
\text { lapor SPT } \\
\text { (orang) }\end{array}$ & $\begin{array}{c}\text { WPOP } \\
\text { belum lapor } \\
\text { SPT (orang) }\end{array}$ & $\begin{array}{c}\text { Persentase } \\
\text { Kepatuhan } \\
\text { WPOP }\end{array}$ \\
\hline 1 & 2015 & 40.502 & 20.118 & 20.384 & 49,67 \\
2 & 2016 & 44.429 & 27.005 & 17.424 & 60,78 \\
3 & 2017 & 47.935 & 27.612 & 20.323 & 57,60 \\
4 & 2018 & 51.598 & 26.711 & 24.887 & 51,76 \\
\hline
\end{tabular}

Sumber: KPP Pratama Badung Utara, 2019

Tingkat kepatuhan wajib pajak orang pribadi di KPP Pratama Badung Utara terlihat fluktuatif. Hal ini terlihat dari meningkatnya kepatuhan dari tahun 2015 sebesar 49,67 persen ke tahun 2016 sebesar 60,78 persen kemudian mengalami penurunan di tahun 2017 sebesar 57,60 persen dan kembali 
mengalami penurunan sebesar 51,76 persen. Kewajiban seorang wajib pajak tidak hanya mendaftarkan diri sebagai wajib pajak, tetapi juga menghitung, membayar dan melaporkan SPT tepat waktu. Sementara kewajiban Direktorat Jenderal Pajak (DJP) adalah mengawasi kegiatan, melakukan pemeriksaan dan penyidikan bagi pelanggar pajak agar wajib pajak selalu patuh (Asrinanda, 2018). Pemerintah dalam hal ini DJP harus melakukan berbagai upaya baik dari sosialisasi, penerapan kebijakan dan eksekusi yang matang (Istiqomah, 2017).

Mengikuti tax amnesty yang dilaksanakan oleh Direktorat Jenderal Pajak adalah salah satu upaya untuk meningkatkan kepatuhan wajib pajak. Penelitian dari Rorong et al., (2017) dan Husnurrosyidah (2016) menyatakan bahwa tax amnesty berpengaruh positif pada kepatuhan wajib pajak, dilihat dari penelitian tersebut dapat disimpulkan bahwa semakin baik dan tegas kebijakan tax amnesty maka kepatuhan wajib pajak akan meningkat, begitupun sebaliknya. Berdasarkan hasil penelitian terdahulu, dapat dirumuskan hipotesis sebagai berikut.

$\mathrm{H}_{1}$ : Tax amnesty berpengaruh positif terhadap kepatuhan wajib pajak.

Ditetapkannya suatu sanksi dalam perpajakan bertujuan untuk meningkatkan kepatuhan wajib pajak, sanksi diberlakukan bagi pelanggar pajak agar tidak melakukan pelanggaran yang bisa mengakibatkan kerugian bagi Negara. Menurut penelitian yang dilakukan Suryanti \& Sari (2018), Husnurrosyidah (2016), dan Savitri \& Nuraina (2017) menyatakan bahwa sanksi perpajakan berpengaruh positif dan signifikan terhadap kepatuhan wajib pajak. Berdasarkan hasil penelitian terdahulu, maka dapat dirumuskan hipotesis sebagai berikut.

$\mathrm{H}_{2}$ : Sanksi perpajakan berpengaruh positif terhadap kepatuhan wajib pajak.

Pelayanan perpajakan yang baik diharapkan mampu meningkatkan kepatuhan wajib pajak. Dalam penelitian yang dilakukan oleh Harmenita, Musadieq, \& Ruhana (2016), Suryanti \& Sari (2018), dan Jotopurnomo \& Mangoting (2013) menyatakan bahwa kualitas pelayanan pajak berpengaruh positif terhadap kepatuhan wajib pajak. Pelayanan yang tepat dan benar oleh aparatur pajak akan memberikan kenyamanan bagi wajib pajak. Berdasarkan hasil penelitian terdahulu, maka dapat dirumuskan hipotesis sebagai berikut.

$\mathrm{H}_{3}$ : Kualitas pelayanan fiskus berpengaruh positif terhadap kepatuhan wajib pajak.

\section{METODE PENELITIAN}

Penelitian dilakukan dengan pendekatan kuantitatif dilaksanakan di Kantor Pelayanan Pajak Pratama Badung Utara di Jl. Ahmad Yani No.100, Dauh Puri Kaja, Kec. Denpasar Utara, Bali. Alasan pemilihan lokasi dikarenakan persentase kepatuhan dari wajib pajak orang pribadi terlihat fluktuaktif, selain itu cakupan wilayah kerjanya sangat luas sehingga hal ini bisa mendukung penelitian yang dilakukan.

Objek pada penelitian ini yaitu kepatuhan wajib pajak orang pribadi yang dipengaruhi oleh tax amnesty, sanksi perpajakan dan kualitas pelayanan fiskus. Variabel independent penelitian ini adalah tax amnesty $\left(\mathrm{X}_{1}\right)$, sanksi perpajakan $\left(\mathrm{X}_{2}\right)$ dan kualitas pelayanan fiskus $\left(\mathrm{X}_{3}\right)$, sedangkan variabel dependent penelitian ini adalah kepatuhan wajib pajak orang pribadi $(Y)$. 
Tax amnesty merupakan salah satu kebijakan yang dilakukan untuk meningkatkan kepatuhan wajib pajak dengan mengungkapkan harta yang belum diungkapkan secara keseluruhan. Sanksi perpajakan diterapkan guna melihat seberapa patuh wajib pajak pada kewajibannya sanksi yang diterapkan bisa meningkatkakan kepatuhan wajib pajak. Pelayanan fiskus merupakan pemberian pelayanan dalam perpajakan seperti membantu menjelaskan prosedur pengisian SPT dan lainnya yang diberikan oleh aparatur pajak kepada wajib pajak. Kepatuhan wajib pajak dilihat dari ketepatan wajib pajak dalam melaporkan kewajiban perpajakan serta mengikuti semua sistem perpajakan yang sudah ada dan bersedia menerima sanksi jika melanggar. Item pernyataan diukur dengan skala Likert 5 poin. Seluruh variabel penelitian diukur dengan skala Likert 5 poin. yaitu 1) sangat tidak setuju, bernilai 1 poin. (2) tidak setuju, bernilai 2 poin. (3) netral, bernilai 3 poin. (4) setuju, bernilai 4 poin. (5) sangat setuju, bernilai 5 poin.

Data kuantitatif yang digunakan adalah tingkat kepatuhan wajib pajak orang pribadi serta hasil jawaban kuesioner yang telah disebarkan kepada wajib pajak di KPP Pratama Badung Utara. Data yang digunakan dalam penelitian ini bersumber dari data primer atau data yang diperoleh secara langsung. Instrumen penelitian yang digunakan adalah uji validitas dan uji reliabilitas.

Populasi yang digunakan adalah wajib pajak yang sudah lapor SPT di KPP Pratama Badung Utara yaitu sebanyak 26.711 orang. Metode penentuan sampel yang dipilih adalah accidental sampling atau dengan kata lain responden tak sengaja bertemu dengan peneliti dan cocok digunakan sebagai sampel sebanyak 100 responden. Metode sampel menggunakan pendekatan slovin sebagai berikut.

$\mathrm{n}=\mathrm{N} /(1+\mathrm{N} .(\varepsilon) 2)=$

Keterangan:

$\mathrm{n}=$ Jumlah Sampel

$\mathrm{N}=$ Jumlah Total Populasi

$\mathrm{e}=$ Batas Toleransi Error $(0,10)$

Hasil perhitungan didapatkan sampel 99,62 dibulatkan menjadi 100.

Teknik analisis data dalam penelitian ini berupa uji statistik deskriptif, uji asumsi klasik (uji normalitas, multikolinearitas dan heteroskedastisitas) dan uji regresi linier berganda.

Persamaan regresi yang digunakan dalam penelitian ini yaitu:

$Y=\alpha+\beta_{1} X_{1}+\beta_{2} X_{2}+\beta_{3} X_{3} \varepsilon$

\section{HASIL DAN PEMBAHASAN}

KPP Pratama Badung Utara merupakan salah satu kantor wilayah Direktorat Jenderal Pajak Bali yang melakukan kegiatan pelayanan terhadap wajib pajak. Hasil dari kuesioner menyatakan bahwa karakteristik responden laki-laki dengan persentase 66 persen atau sebanyak 66 orang dan perempuan dengan 34 persen atau sebanyak 34 orang, responden berusia dibawah 30 tahun dengan persentase 58 persen atau sebanyak 58 orang, umur 30-50 tahun sebesar 28 persen atau sebanyak 28 orang dan usia diatas 50 tahun sebesar 24 persen atau 24 orang. Tingkat pendidikan terakhir sebagian besar responden berjenjang S1 dengan persentase 69 persen atau sebanyak 69 orang, SMA/Sederajat sebesar 18 persen atau sebanyak 18 orang, S2 sebesar 9 persen sebanyak 9 orang dan jenjang 
S3 sebesar 4 persen sebanyak 4 orang. Berdasarkan pekerjaan, sebagian besar responden bekerja sebagai wiraswasta dengan persentase 73 persen atau sebanyak 73 orang dan sisanya sebanyak 27 persen atau 27 orang pekerjaan lainnya. Pengujian validitas dalam penelitian bertujuan untuk menguji valid atau tidak valid data dari suatu kuesioner.

Tabel 3. Hasil Uji Validitas

\begin{tabular}{|c|c|c|}
\hline Variabel & Item Pertanyaan & Koefisien Korelasi \\
\hline \multirow{5}{*}{ Tax Amnesty $\left(\mathrm{X}_{1}\right)$} & $\mathrm{X}_{1,1}$ & 0,636 \\
\hline & $\mathrm{X}_{1,2}$ & 0,848 \\
\hline & $\mathrm{X}_{1,2}$ & 0,770 \\
\hline & $\mathrm{X}_{1.4}$ & 0,730 \\
\hline & $\mathrm{X}_{1.5}$ & 0,745 \\
\hline \multirow[t]{5}{*}{ Sanksi Perpajakan $\left(\mathrm{X}_{2}\right)$} & $\mathrm{X}_{2,1}$ & 0,687 \\
\hline & $\mathrm{X}_{2,2}$ & 0,634 \\
\hline & $\mathrm{X}_{2, \mathrm{a}}$ & 0,597 \\
\hline & $\mathrm{X}_{2,4}$ & 0,552 \\
\hline & $\mathrm{X}_{2.5}$ & 0,527 \\
\hline \multirow{5}{*}{$\begin{array}{l}\text { Kualitas Pelayanan Fiskus } \\
\left(\mathrm{X}_{\mathrm{a}}\right)\end{array}$} & $\mathrm{X}_{\mathrm{a}, 1}$ & 0,676 \\
\hline & $\mathrm{X}_{\mathrm{a}, 2}$ & 0,755 \\
\hline & $\mathrm{X}_{\mathrm{a}, \mathrm{a}}$ & 0,663 \\
\hline & $\mathrm{X}_{\mathrm{a}, 4}$ & 0,809 \\
\hline & $\mathrm{X}_{2.5}$ & 0,858 \\
\hline \multirow{5}{*}{ Kepatuhan WPOP $(\mathrm{Y})$} & $Y_{1}$ & 0,551 \\
\hline & $\mathrm{Y}_{2}$ & 0,816 \\
\hline & $\mathrm{Y}_{3}$ & 0,790 \\
\hline & $\mathrm{Y}_{4}$ & 0,753 \\
\hline & $Y_{5}$ & 0,637 \\
\hline
\end{tabular}

Sumber: Data Penelitian, 2019.

Hasil uji menunjukkan nilai Pearson Correlation dari variabel yang diteliti menunjukkan hasil positif dan besarnya diatas 0,30 . Disimpulkan semua variabel yang akan diteliti adalah valid atau layak untuk diteliti.

Pengujian ini dilakukan untuk menunjukkan suatu instrumen dikatakan andal apabila jawaban responden terhadap kuesioner adalah konsisten atau stabil. Reliabilitas suatu data dikatakan reliabel jika koefisien Alpha Croncbach's lebih besar dari 0,60 .

\section{Tabel 4. Hasil Uji Reliabilitas}

\begin{tabular}{ll}
\hline Variabel & Alpha Croncbach's \\
\hline Tax Amnesty $\left(\mathrm{X}_{1}\right)$ & 0,762 \\
Sanksi Perpajakan $\left(\mathrm{X}_{2}\right)$ & 0,662 \\
Kualitas Pelayanan Fiskus $\left(\mathrm{X}_{\mathrm{a}}\right)$ & 0,783 \\
Kepatuhan Wajib Pajak Orang Pribadi $(\mathrm{Y})$ & 0,729 \\
\hline
\end{tabular}

Sumber: Data Penelitian, 2019.

Hasil pengujian menunjukkan Alpha Croncbach's dari masing-masing variabel lebih besar dari 0,60 yang berarti keseluruhan item pada kuesioner dari variabel dalam penelitian ini adalah reliabel dan dapat digunakan. 
Analisis statistik deskriptif suatu penelitian bertujuan memberikan analisis deskripsi suatu data secara keseluruhan.

Tabel 5. Hasil Analisis Statistik Deskriptif

\begin{tabular}{lccccc}
\hline \multicolumn{1}{c}{ Var. } & N & Minimum & Maksimum & Rata-rata & $\begin{array}{c}\text { Standar } \\
\text { Deviasi }\end{array}$ \\
\hline Tax Amnesty & 100 & 15 & 25 & 20,77 & 1,847 \\
Sanksi Perpajakan & 100 & 15 & 25 & 19,93 & 1,754 \\
$\begin{array}{l}\text { Kualitas Pelayanan } \\
\text { Fiskus }\end{array}$ & 100 & 12 & 24 & 19,89 & 1,517 \\
Kepatuhan WPOP & 100 & 17 & 24 & 20,47 & 1,374 \\
\hline
\end{tabular}

Sumber: Data Penelitian, 2019

Hasil uji menunjukkan nilai minimum dari variabel tax amnesty 15, nilai maksimum 25 dengan rata-rata 20,77 dan memiliki standar deviasi sebesar 1,847 yang menunjukkan nilai dari variabel tax amnesty tersebut bervariasi. Hasil analisis variabel sanksi perpajakan memiliki nilai minimum 15, nilai maksimum 25 dengan rata-rata 19,93 dan standar deviasi 1,754 yang menunjukkan nilai variabel sanksi perpajakan tersebut bervariasi. Nilai dari variabel kualitas pelayanan fiskus terlihat bervariasi yang dapat dilihat dari nilai minimum 12, nilai maksimum 24 dengan rata-rata 19,89 dan standar deviasi 1,517. Hasil analisis kepatuhan wajib pajak juga bervariasi dengan nilai minimum 17, nilai maksimum 24 dengan rata-rata 20,47 dengan standar deviasi 1,374.

Uji normalitas ini digunakan untuk mengetahui bila suatu data berdistribusi normal atau tidak, maka akan digunakan uji Kolmogorov-Smirnov.

Tabel 6. Hasil Uji Normalitas

\begin{tabular}{lc}
\hline \multicolumn{1}{c}{ Keterangan } & Unstandardlized Residual \\
\hline $\mathrm{N}$ & 100 \\
Kolmogorov-Smirnov $\mathrm{Z}$ & 1,225 \\
Asymp. Sig. (2-tailed) & 0,100
\end{tabular}

Sumber: Data Penelitian, 2019

Hasil uji membuktikan bahwa nilai Asymp. Sig. (2-tailed) $=0,100$ dengan nilai Kolmogorov-Smirnov $Z=1,225$. Hal tersebut menunjukkan bahwa nilai Asymp. Sig. (2-tailed) 0,100 >0,05 dapat disimpulkan bahwa variabel-variabel dalam penelitian berdistribusi normal.

Uji multikolinearitas dilakukan untuk menguji jika ada atau tidak ada korelasi antar variabel independent.

Tabel 7. Hasil Uji Multikolinearitas

\begin{tabular}{lcc}
\hline \multicolumn{1}{c}{ Variabel } & Tolerance & VIF \\
\hline Tax Amnesty $\left(\mathrm{X}_{1}\right)$ & 0,981 & 1,020 \\
Sanksi Perpajakan $\left(\mathrm{X}_{2}\right)$ & 0,972 & 1,029 \\
Kualitas Pelayanan Fiskus $\left(\mathrm{X}_{\mathrm{a}}\right)$ & 0,966 & 1,035 \\
\hline
\end{tabular}

Sumber: Data Penelitian, 2019.

Hasil uji multikolinearitas membuktikan nilai tolerance keseluruhan variabel lebih besar dari 0,10 dan nilai VIF kurang dari 10, yang berarti bahwa keseluruhan variabel telah bebas dari multikolinearitas.

Uji heteroskedastisitas bertujuan untuk mengetahui jika terjadi ketidaksamaan varian untuk semua pengamatan pada model regresi linier. 
Tabel 8. Hasil Uji Heteroskedastisitas

\begin{tabular}{lc}
\hline \multicolumn{1}{c}{ Variabel } & Sig. \\
\hline Tax Amnesty & 0,731 \\
Sanksi Perpajakan & 0,386 \\
Kualitas Pelayanan Fiskus & 0,524 \\
\hline
\end{tabular}

Sumber: Data Penelitian, 2019.

Hasil uji heteroskedastisitas membuktikan bahwa keseluruhan variabel memiliki nilai sig. lebih dari 0,05. Disimpulkan bahwa keseluruhan variabel dikatakan bebas dari heteroskedastisitas.

Analisis regresi berganda bertujuan untuk menguji pengaruh dari tax amnesty $\left(\mathrm{X}_{1}\right)$, sanksi perpajakan $\left(\mathrm{X}_{2}\right)$, dan kualitas pelayanan fiskus $\left(\mathrm{X}_{3}\right)$, terhadap kepatuhan wajib pajak orang pribadi $(Y)$ yang terdaftar di KPP Pratama Badung Utara.

Tabel 8. Hasil Analisis Regresi Linier Berganda

\begin{tabular}{|c|c|c|c|c|c|}
\hline $\begin{array}{l}\text { Variabel } \\
\text { Terikat }\end{array}$ & Variabel Bebas & $\begin{array}{c}\text { Koefisien } \\
\text { Regresi }\end{array}$ & $\begin{array}{c}\text { Standard } \\
\text { Error }\end{array}$ & t-hitung & Sig. \\
\hline Kepatuhan & Tax Amnesty $\left(\mathrm{X}_{1}\right)$ & 0,661 & 0,069 & 9,651 & 0,000 \\
\hline Wajib Pajak & Sanksi Perpajakan $\left(X_{2}\right)$ & 0,328 & 0,078 & 4,225 & 0,000 \\
\hline Orang & Kualitas Pelayanan & & & & \\
\hline \multirow[t]{2}{*}{ Pribadi (Y) } & Fiskus $\left(X_{3}\right)$ & 0,523 & 0,086 & 6,044 & 0,000 \\
\hline & $\begin{array}{l}\text { Constant } \\
\text { Adjusted R Square }\end{array}$ & $\begin{array}{l}=-9,474 \\
=0,610\end{array}$ & $\begin{array}{l}\text { F-Hitung } \\
\text { Sig }\end{array}$ & $\begin{array}{l}=52,547 \\
=0,000\end{array}$ & \\
\hline
\end{tabular}

Sumber: Data Penelitian, 2019

Berikut hasil dari persamaan regresi linier berganda.

$$
\mathrm{Y}=-9,474+0,661 \mathrm{X}_{1}+0,328 \mathrm{X}_{2}+0,523 \mathrm{X}_{3}
$$

Hasil dari analisis regresi linier berganda menunjukkan hasil koefisien regresi tax amnesty $\left(\mathrm{X}_{1}\right)=0,661$ yang berarti jika tax amnesty meningkat satu satuan, maka kepatuhan wajib pajak orang pribadi akan meningkat sebesar 0,661 satuan. Hasil koefisien regresi sanksi perpajakan $\left(\mathrm{X}_{2}\right)=0,328$ yang berarti jika sanksi perpajakan meningkat satu satuan, maka kepatuhan wajib pajak orang pribadi akan meningkat sebesar 0,328 satuan. Koefisien regresi kualitas pelayanan fiskus $\left(X_{3}\right)=0,523$ yang berarti jika kualitas pelayanan fiskus meningkat satu satuan, maka kepatuhan wajib pajak orang pribadi akan meningkat sebesar 0,523 satuan. Nilai adjusted $R^{2}$ sebesar 0,610. Menunjukkan 61 persen faktor kepatuhan wajib pajak orang pribadi di KPP Pratama di Badung Utara dipengaruhi oleh tax amnesty, sanksi perpajakan dan kualitas pelayanan fiskus, sedangkan sebesar 39 persen dipengaruhi oleh variabel lain. Hasil pengujian didapatkan nilai $\mathrm{F}$ sebesar 52,574 dengan signifikasi 0,000 yang lebih kecil dari nilai $a=0,005$, yang berarti model regresi dapat digunakan untuk memprediksi penelitian ini.

Hasil dari uji hipotesis (uji t) dilakukan menguji pengaruh secara parsial antara variabel independent dengan variabel dependent. Hasil pengujian nilai sig.t variabel tax amnesty adalah 0,000 atau lebih kecil dari 0,005 dengan koefisien regresi $\left(\beta_{1}\right)$ bernilai positif sebesar 0,661 . Disimpulkan $\mathrm{H}_{1}$ diterima yang berarti tax amnesty berpengaruh terhadap kepatuhan wajib pajak orang pribadi. Nilai 
regresi dari variabel tax amnesty menunjukkan hasil yang positif yang berarti menunjukkan hubungan yang searah antara tax amnesty dan kepatuhan wajib pajak orang pribadi. Penelitian dari Rorong et al., (2017) dan Husnurrosyidah (2016) mendukung penelitian ini dengan menyatakan bahwa semakin baik penerapan dan eksekusi dari kebijakan dari tax amnesty maka akan berpengaruh terhadap peningkatan kepatuhan wajib pajak orang pribadi.

Hasil uji hipotesis didapatkan nilai sig.t variabel sanksi perpajakan adalah 0,000 atau lebih kecil dari 0,005 dengan koefisien regresi $\left(\beta_{2}\right)$ bernilai positif sebesar 0,328. Disimpulkan bahwa $\mathrm{H}_{0}$ ditolak dan $\mathrm{H}_{2}$ diterima, yang berarti sanksi perpajakan berpengaruh pada kepatuhan wajib pajak orang. Nilai regresi dari variabel sanksi perpajakan menunjukkan hasil yang positif yang berarti menunjukkan hubungan yang searah antara sanksi perpajakan dan kepatuhan wajib pajak orang pribadi. Penelitian dari Suryanti \& Sari (2018) dan Husnurrosyidah (2016) mendukung penelitian dengan menyatakan bahwa semakin tegas penerapan sanksi, akan mampu meningkatkan kepatuhan wajib pajak orang pribadi.

Hasil uji hipotesis didapatkan nilai sig.t variabel tax amnesty adalah 0,000 atau lebih kecil dari 0,005 dengan koefisien regresi $\left(\beta_{3}\right)$ yang bernilai positif sebesar 0,523. Disimpulkan $\mathrm{H}_{0}$ ditolak dan $\mathrm{H}_{3}$ diterima, yang berarti variabel kualitas pelayanan fiskus berpengaruh pada kepatuhan wajib pajak orang pribadi. Nilai regresi menunjukkan hasil yang positif yang berarti menunjukkan hubungan yang searah antara kualitas pelayanan fiskus dan kepatuhan wajib pajak orang pribadi. Penelitian dari Harmenita et al., (2016) dan Suryanti \& Sari (2018) menyatakan bahwa semakin baik pelayanan serta tepat dan jelas suatu informasi yang diberikan maka akan meningkatan kepatuhan wajib pajak orang pribadi.

\section{SIMPULAN}

Berdasarkan hasil dan pembahasan, disimpulkan bahwa kebijakan tax amnesty berpengaruh positif pada kepatuhan wajib pajak orang pribadi, hal ini berarti semakin baik dan tegas penerapan serta pelaksanaan kebijakan tax amnesty maka akan berpengaruh pada peningkatan kepatuhan wajib pajak. Seiring dengan dengan ditetapkannya suatu kebijakan, akan ada sanksi yang diberikan bagi pelanggar pajak, disimpulkan bahwa sanksi perpajakan berpengaruh positif pada kepatuhan wajib pajak orang pribadi. Kualitas pelayanan fiskus yang baik dan tanggap akan membantu wajib pajak dalam memenuhi kewajiban perpajakannya, hal ini berarti bahwa kualitas pelayanan akan mempengaruhi kepatuhan wajib pajak orang pribadi. Keterbatasan dalam penelitian ini, masih terdapat faktor lain yang dapat mempengaruhi kepatuhan wajib pajak orang pribadi salah satunya kesadaran wajib pajak, disarankan bagi peneliti selanjutnya untuk menggunakanya sebagai variabel penelitian. 


\section{REFERENSI}

Asrinanda, Y. (2018). The Effect of Tax Knowledge, Self Assessment System, and Tax Awareness on Taxpayer Compliance The Effect of Tax Knowledge, Self Assessment System, and Tax Awareness on Taxpayer Compliance. 8(10), 539-550. https://doi.org/10.6007/IJARBSS/v8-i10/4762

Damayanti, T. W., Sutrisno, T., Subekti, I., \& Baridwan, Z. (2015). The Role of Taxpayer' s Perception of the Government and Society to Improve Tax Compliance. 4(1). https:/ / doi.org/10.5430/afr.v4n1p180

Darmawan, A. (2016). Indonesia's Tax Amnesty Law Based On The Perspective Of The Law As An Allocative System. 5(3), 509-527. https://doi.org/10.20961/yustisia.v5i3.8788

Diamastuti, E., \& Hardanti, K. N. (2019). The Investigation Of Taxplayer Compliance In Tax Amnesty. Akrual: Jurnal Akuntansi 10(1). http:/ /dx.doi.org/10.26740/jaj.v10n2.p85-104 .

Dewi, E., \& Noviari, N. (2019). Pengaruh Kesadaran Wajib Pajak, Pelayanan Fiskus, \& Sanksi Perpajakan Pada Kemauan Mengikuti Tax Amnesty. EJurnal Akuntansi Universitas Udayana. 19(2), 1378-1405.

Fitria, D., Abdillah, A., Prasetyono, H., \& Cahyo, I. D. (2019). The Difference of Enterprises Taxpayers Compliance after Tax Amnesty. 12(24), 86-99. https://doi.org/10.15294/jejak.v12i1.16555

Harmenita, R., Musadieq, M. Al, \& Ruhana, I. (2016). Pengaruh Kualitas Pelayanan Fiskus Terhadap Reinventing Policy Dan Kepatuhan Wajib Pajak (Studi pada Wajib Pajak Badan yang Terdaftar di Kantor Pelayanan Pajak Madya Bekasi). 9(1), 1-7.

Hayat, M., \& Kristanto, R. (2018). Pengaruh Pengampunan Pajak Dan Kemudahan Administrasi Pajak Terhadap Kepatuhan Wajib Pajak Orang Pribadi Pada Kpp Pratama Jakarta Penjaringan. 1(2), 218-234. 10.31334/trans.v1i2.305.

Husnurrosyidah. (2016). Pengaruh Tax Amnesty Dan Sanksi Pajak Terhadap Kepatuhan Pajak di Bmt Se-Karasidenan Pati. 4(2), 211-226. journal.stainkudus.ac.id/index.php/equilibrium

Istighfarin, N., \& Fidiana. (2018). Tax Amnesty Dari Perspektif Masyarakat Pajak. 9(2), 142-156. http://dx.doi.org/10.26740/jaj.v9n2.p142-156

Istiqomah. (2017). Analisis Kepatuhan Wajib Pajak Orang Pribadi Berkaitan dengan Adanya Kebijakan Penghapusan Sanksi Pajak. VI, 81-92. https://doi.org/10.21831/nominal.v6i1.14334

Jaya, A., Ratnawati, T., \& Sardjono, S. (2017). Analysis of Effect of Knowledge and Service Quality, Accessibility of Information, Awareness and Behavior of Taxpayers and Impact on Satisfaction and Compliance With Taxpayers of Land and Buildings in The City Batam Island Riau Province. 6(8), 73-83.

Jotopurnomo, C., \& Mangoting, Y. (2013). Pengaruh Kesadaran Wajib Pajak, Kualitas Pelayanan Fiskus, Sanksi Perpajakan, Lingkungan Wajib Pajak Berada terhadap Kepatuhan Wajib Pajak Orang Pribadi di Surabaya. 1(1), 49-54.

Madjid, S. (2015). The Effect Tax Audit Quality and Service Quality On Tax Reporting Compliance ( The cases of tax audit of Indonesian ). 6(12), 131135. 
Mujahid, A., \& Ahmed, D. (2019). International Journal of Social and Administrative Sciences The Effect Of Tax Amnesties Programs On Tax Collection And Economic Performance: A Global Macro Keywords. 4(2), 108-128. https://doi.org/10.18488/journal.136.2019.42.108.128.

Natania, E. S. (2018). An Accounting Perspective of Tax Amnesty in Indonesia. 1(1), 1-17. https://doi.org/10.24198/jaab.v1i1.15645

Nuryati, T., \& Pratama, B. (2019). Tax Amnesty as a Contribution to the Improvement of Taxpayers ' Compliance. 234-237. https://doi.org/10.2991/aicar-18.2019.51

Olaoye, C. O., Ayeni-agbaje, A. R., \& Alaran-ajewole, A. P. (2017). Tax Information, Administration and Knowledge on Tax Payers ' Compliance of Block Moulding Firms in Ekiti State. 5(4), 131-138. https:/ /doi.org/10.11648/j.jfa.20170504.12

Pravasanti, Y. A. (2018). Dampak Kebijakan dan Keberhasilan Tax Amnesty Bagi Perekonomian Indonesia. 16(1), 84-94. https://doi.org/10.30595/kompartemen.v16i1.2415

Purnamasari, D., \& Sudaryo, Y. (2018). The Effect of Knowledge Taxpayer , Moral Taypayer and Tax Sanctions on Taxpayers Compulsory. 9(5). https://doi.org/10.18178/ijtef.2018.9.5.618

Rorong, E. N., Kalangi, L., \& Runtu, T. (2017). Pengaruh Kebijakan Tax Amnesty, Kesadaran Wajib Pajak Dan Sanksi Pajak Terhadap Kepatuhan Wajib Pajak Orang Pribadi Di Kpp Pratama Manado. 12(2), 175-187. https://doi.org/10.32400/gc.12.2.17480.2017

Savitri, F. \& Nuraina. (2017). Pengaruh Sanksi Perpajakan terhadap Kepatuhan Wajib Pajak Orang Pribadi di Kantor Pelayanan Pajak Pratama Madiun. 5(1), 45-55. http://doi.org/10.25273/equilibrium.v5i1.1005

Saraswati, Z. E., Masitoh, E., \& Dewi, R. R. (2018). Tax Awareness, Modern Tax Administration System And Tax Sanctions Against Taxpayer Compliance. $4(2), 66-75$.

Sari, D., \& Mulyati, Y. (2018). The Impact of Tax Amnesty on Tax Revenue and Tax Ratio: Case in Indonesia. 7, 245-247. http://doi.org/10.14419/ijet.v7i4.34.23899.

Sumanjaya, W. (2019). Tax Amnesty Policy Analysis : Concepts And Applications In Indonesia. 7(6), 133-144.

Suryanti, H., \& Sari, I. H. (2018). Pengaruh Sanksi Perpajakan, Pelayanan Fiskus Dan Pengetahuan Perpajakan Terhadap Kepatuhan Wajib Pajak Orang Pribadi (Studi pada Kantor Pelayanan Pajak Pratama Jakarta Pancoran). 16(2), 14-26.

Susan, Novitasari. (2018). Menyingkap Fenomena Tax amnesty di Indonesia: Sebuah Analisis dengan Pendekatan Luder's Contingency Model. E-Jurnal $\begin{array}{lll}\text { Universitas } \quad \text { Airlangga, 1(1), } & \text { 73-93. }\end{array}$ http://dx.doi.org/10.21043/aktsar.v1i1.3830

Suyanto, \& Pratama, Y. (2018). Kepatuhan wajib pajak orang pribadi: Studi aspek pengetahuan, kesadaran, kualitas layanan dan kebijakan sunset policy 21(1), 139-158. https://doi.org/10.24914/jeb.v21i1.704

Wirawan, A., \& Noviari, N. (2017). Pengaruh Penerapan Kebijakan Tax amnesty dan Kualitas Pelayanan Fiskus terhadap Kepatuhan Wajib Pajak Orang 
Pribadi. E-Jurnal Akuntansi Universitas Udayana 21(3), 2165-2194. https://doi.org/10.24843/EJA.2017.v21.i03.p1.

Wiryadana, I., \& Lely, A. (2018). Pengaruh Kualitas Pelayanan, Sanksi Pajak, Biaya Kepatuhan Pajak dan E-Filling Pada Kepatuhan WPOP Non PNS. EJurnal Akuntansi Universitas Udayana, 25(3), 1773 - 1798. https://doi.org/10.24843/EJA.2018.v25.i03.p06 